\title{
Creating an Alternate Canon: Achebe to Obioma
}

\author{
Virender Pal \\ Assistant Professor of English, Institute of Honors and Integrated Studies, Kurukshetra \\ University Kurukshetra, Haryana, India. \\ ORCID id: oooo-0003-3569-1289. E-mail:p2vicky@gmail.com
}

\begin{abstract}
Chigozie obioma is a novelist of Nigerian origin who has published two novels so far. He has been hailed as an 'heir to Chinua Achebe' the master African novelist. The comparison of Obioma with Achebe is obvious because both of them belong to the same tribe, but what is more important is that Obioma seems to carry from the point where Achebe left. In his debut novel The Fishermen, Obioma foregrounds the problems that plague postcolonial Nigeria. In the novel he confirms that whatever Achebe prophesised about the future of Nigeria has come true. Like his illustrious predecessor he is critical of colonial institutions that have decimated the national culture of Nigeria. The paper is a study of Obioma's novel The Fishermen.
\end{abstract}

Keywords: Nigeria, Christianity, Obioma, Achebe, Fishermen.

Even as it has become intellectually axiomatic to question and dismiss the concept of canon; though canon has been challenged as an imposition of Western intellectual tradition and a limitation set by imperialist discourse aiding and abetting hegemony of the colonizers, yet undeniably there is a body of works that are piling up on the other side calling for recognition and covertly inviting a label- a canon formed of motley crew of writers who have resisted earlier discourses so impressively that these threaten not just to pull down the sacrosanct fiction included under the banner of 'canon' but to usurp their place and exude the aura and exercise the influence that the Western canon had done earlier. Of course, it would be a discursive blasphemy of sorts for postcolonial writing to admit that they have their own canon much as the European masters had their own. Not only this, but that the clout affected globally matches and eclipses the ability to resonate with the present readernot naive but the sentimental reader identified by critics and writers like Schiller, Pamuk and a plethora of Reader-Response theorists.

The established canon continues to occupy the hall-of-fame and elevated status but they are overshadowed by the glowering texts that voice the story from the subaltern or marginalized side. Chigozie Obioma has been hailed as an "heir to Chinua Achebe" (Rocco). It is indeed a truly remarkable achievement to be declared as Achebe's heir because "Chinua Achebe achieved canonization with his first novel Things Fall Apart, and he has retained his top ranking in the African literary canon" (Izevbaye 2009, p.31) and he is credited with inventing the African literature (Gikandi 2001, p.5). This may be a non-academic description of both the popular and the academic recognition received by postcolonial writers.

\footnotetext{
(c) AesthetixMS 2021. This Open Access article is published under a Creative Commons Attribution Non-Commercial 4.0 International License (http://creativecommons.org/licenses/by-nc/4.o/), which permits non-commercial re-use, distribution, and reproduction in any medium, provided the original work is properly cited. For citation use the DOI. For commercial re-use, please contact editor@rupkatha.com.
} 
No doubt Obioma is related to Chinua Achebe through his Igbo ancestry and like his illustrious predecessor he is also preoccupied with Igbo culture so Obioma may be considered as a literary heir to Achebe. In addition to the Ibo connection there is a deeper connection as well and this connection is more important than the first one. Achebe wrote his novels "as a response to the fictions of empire" and eventually his novels became a way "to take a measure of the drastic reordering of African lives by western cultural impositions” (Irele 2009, p.8).

While studying, portraying and repudiating "imperialist and colonial ideology" (Osi-Nyame 2010, p. 5) Achebe became an architect of African literature. Obioma becomes an heir to Achebe by starting from the point where Achebe left. The main preoccupation of Achebe was to portray "an encounter between traditional Igbo religion and Christianity" (Kortenaar 1995, p. 31) and the impact colonialism had on Ibo society. He meticulously studied the impact of colonialism on the Nigerians and presented his study in the garb of fiction to the readers around the world. Obioma does the same thing in his first novel The Fishermen. He studies the impact of colonialism and colonial institutions in the postcolonial Nigeria. On reading The Fishermen, readers realise why Achebe was so critical of Christianity and colonialism.

After reading Obioma's novel, readers realize that Achebe was not only a writer, but he was a prophet who prophesised about the future of Nigeria so accurately. The Fishermen shows that the character of the Nigerians has been altered by the colonialism and its institutions. The Ibo people are no longer the children of Okonkwo rather they have become deracinated Nigerians, some sort of pseudo-whites who have forgotten their nativity, remained ignorant of their ancestry, have lost their rationality, their culture and most importantly their identity. They have become nowhere people. In The Fishermen, readers realize that though Nigeria has achieved freedom from the colonial rule, yet an invisible colonial hand controls the minds of the Nigerians and it is accomplished through colonial institutions namely Christianity, western education and democracy. One is reminded of Ngugi wa Thiong'o words in this context. He wrote in Decolonising the Mind:

In the eighteenth and nineteenth centuries Europe stole art treasures from Africa to decorate their houses and museums; in the twentieth century Europe is stealing the treasures of mind to enrich their languages and cultures. Africa needs back its economy, its politics, its culture, its languages and all its patriotic writers. (p. XII)

Obioma in The Fishermen makes clear that Nigeria definitely needs its own economy, culture and language.

Cedric Courtois (2019) in his paper on the novel call the novel a "Bildungsroman," a novel that relates to the growth or career of a protagonist as Pamuk reaffirms because the book tells the story from the point of view of a boy Benjamin who at the beginning of the story is a nine years old boy. The story is about his brothers Ikenna, Boja, Obembe and his parents James Agwu and Paulina Agwu. He has two more siblings David and Nkem, but they are infants at the time of the story. No doubt the story is told by Benjamin who attains adulthood towards the end of the novel, but story is not so simple because the story is really about the society and the country.

\section{The narrative}

Obioma uses a young boy as a narrator to add authenticity to his story as a young boy of nine can only narrate the truth what has happened in front of his eyes; adding anything from his own side seems beyond his capability. 
Obioma while making Benjamin tell the story shows that he is vulnerable like all the boys of his age, this makes the story more veracious. Benjamin while telling the story of his family brings the problems of Nigeria in foreground. The whites claimed that they brought civilization to Africa and in fact the colonial narratives eulogized early colonisers' persistence and perseverance because Africa was slow in "responding to the light of civilization" (Kadiatu 1998, p. 13).

\section{Alienating Cultures; Totalitarian Religions}

Though there may be schisms within a religion, a racial group subscribing to such an internally torn religion becomes a composite entity when encountering another race or an alien people. Christianity, at least, has shown this uncanny ability in the Crusades and Medieval ages and even post-reformation times- Catholics, Protestants, Presbyterians, Lutherans- the internal dissensions disappear as European powers encounter the African or the exotic Middle East- especially, in discourse. The French and the British may be at loggerheads as political powers in East India but the imperial discourse or the academic approach called Orientalism served both political powers equally well. Similarly, the missionary discourse to shepherd the stray and civilize the uncivilized was more bothered about exotic souls than sibling Christian souls of Protestants or Catholics or white democrats or white Republicans.

In the novel, Obioma blasts the bubble of civilizing lies of the whites. The novel tells the story of Nigeria in 1990s, almost thirty years after achieving the independence conditions in Nigeria remain pathetic. Benjamin tells about his father's feelings:

Father was bitter. He bemoaned the poor health facilities in the country. He swore at Abacha, the dictator, and railed on about the marginalization of Igbos in Nigeria. Then he complained about the monster the British had created by forming Nigeria as a whole. (2015, p. 41)

It is clear from the above lines that the British have altered the life of people in Nigeria. They replaced the culture of Nigerians by an alien culture. In postcolonial, educated Nigeria rationality has been replaced by blind faith.

Readers remember Okonkwo asking the missionaries: "you told us with your own mouth that there was only one god. Now you talk about his son. He must have a wife then" (Achebe 2010, p. 107). This rational question of Okonkwo silenced the missionary at that time; but in Obioma's novel readers come across de-cultured Nigerians who have lost their rationality.

The dominance of the British is visible in all the walks of life. Achebe through his writings showed that the Ibos "had a philosophy of a great depth and value and beauty, that they had poetry, and above all, they had dignity" (Achebe 1973, p. 8). In The Fishermen readers realise that the philosophy of the Ibos has waned and it has been replaced by the imposed or superimposed alien imported religion, that is, Christianity. This is obvious in the changed status of the river Omi-Ala:

Like many such rivers in Africa, Omi-Ala was once believed to be a god; people worshipped it. They erected shrines in its name, and courted the intercession and guidance of Iyemoja Osha, mermaids, and other spirits and gods that dwelt in water bodies. This changed when colonialists came from Europe and introduced the Bible, which then prised Omi-Ala's adherents from it, and the people, now largely Christians began to see it as an evil place. A cradle besmeared. (p. 25) 
With the arrival of the colonisers drastic changes came in the society and the sacred became profane. The Nigerians were brainwashed into believing that their whole civilization was a sham; the practices of their ancestors were evil. The inhabitants of Akure were convinced that "fetish rituals" (p. 25) took place on the banks of Omi-Ala. Here Achebe's stand that the "Igbos did not need the white man to carry them into the modern world" (Rhoads 1993, 67) seems correct. What the readers find in the novel are not the modern African men and women; but a poor imitation of the whites who yearn for white- hood.

The greatest catalyst for this change was the church. Military subdued the Africans with their superior weapons, but the long-lasting subservience was brought by the church. It was the church that made the people believe that their religion was heathenish and they were uncivilized barbarians and they needed white man's religion to become civilized. The Church was responsible to causing friction in the closely knit tribal society.

Ngugi wa Thiong'o writes about the role that was played by church as an instrument of colonialism:

Thus, acceptance of the Christian Church meant the outright rejection of all the African customs. It meant rejection of those values and rituals that held us together: it meant adopting what in effect was a debased European middle-class mode of living and behaviour. The European missionary had attacked primitive rites of our people, had condemned our beautiful African dances, the images of our gods, recoiling from their suggestion of satanic sensuality. The early African convert did the same, often with greater zeal, for he had to prove how Christian he through this rejection of his past and roots. (1972, p. 31)

In the novel Chigozie Obioma is critical of over indulgence of the Nigerians in Christianity. While reading the novel readers realize that the converts of Nigeria still retain the zeal of the early converts and that too to the dangerous levels. It becomes clear in the beginning of the novel when Benjamin's brother Ikenna tries to appeal to the conscience of "Christian children to refrain from insulting their parents" (p. 17). In fact, Christianity in the novel is an omnipotent force that dominates everything from sports to personal lives. Achebe prophesised about this aspect of Christianity long ago:

The Ibo's religion did not fully understand the nature of Christianity. Even the next village has a different God, so they must have theirs. They simply thought this was another of same kind, but they were mistaken because this was a totalitarian religion we used to talk about. (Bonneti, 1989, p.77)

What Achebe adumbrated about the totalitarian nature of Christianity is confirmed by Obioma. He shows that traditional gods like Omi-Ala have been declared profane and devilish by the Christianised Nigerians. This domination of Africans by whites is baffling because on the evolutionary scale the white man is only a recent entrant. Cheikh Anta Diop, the leading anthropologist remarks in this regard:

The first white appeared only around 20,0oo years ago: the Cro- Magnan Man. He is probably the result of a mutation from Grimaldi Negroid due to an existence of 20,000 years in the excessively cold climate of Europe at the end of last glaciation. (1991, p. 15-16)

It is interesting to note that the "first inhabitant of Europe was a migrating Black: the Grimaldi Man" (Diop 1991, p. 13) and it seems ironic that racially differentiated white man of Europe, who was a mutated offspring of the Black man, returned to Africa to 'civilize' the land of his ancestors. 


\section{Denying the African roots}

The recent academic assertions that the search for origins is a naive or futile exercise may or may not have been prompted by the discovery that genetically all had a common Black ancestor. Both Creationism of the Bible and Evolutionary theory of Darwin had somehow still allowed a minimum uncertainty over the origins of human species which was comforting. The eugenics following Darwinian premises were used by Adolf Hitler but this discovery taking the whole humanity to Common African roots was just too atrocious to be accepted or acknowledged. Therefore, it was best to dismiss the earlier incessant preoccupation of West as needless- voluntarily. An intellectual leadership which then is left unquestioned by a majority till radical minds challenge such assumptions- whether objective or prejudicial but which become so trendy that they dictate the direction of the whole academic world.

\section{No Episteme outside the West}

How could there have been episteme- as Foucault understands that is recognized as knowledgeanywhere outside West? The West articulated its knowledge and then recognized it as the only way of knowing the world. The relegated ways of knowing have vanished for -ever. Of course, since even when they may have existed the expanse may not have been large for what Nigerian knew- in this sense, what Whites knew was important as his way of life had made irrelevant or accessories the lives and cultures of other communities.

In the process of civilizing his ancestors, the white man destroyed the wisdom that was accumulated by the people over the centuries. Obioma takes a clear stand in the matter and tells the readers that before the arrival of the whites Omi-Ala was "a pure river that supplied the earliest settlers with fish and clean drinking water" (p. 25).

The Nigerians and their wisdom kept Omi-Ala clean for centuries, but the Christianity made them abandon the river and it was turned into a drain of "bracken water" (p. 23) in a matter of years. Obioma suggests that whatever happened with Omi-Ala will happen with other natural things. It was the sacredness of Omi-Ala that had preserved it for centuries, but Christianity branded it devilish and paved the way for its destruction. Pollution and neglect of Omi-Ala confirms the decimation of traditional African belief system which believed:

Gods and spirits are located and embodied in objects: the objects are the physical and material manifestations of gods and spirits... nature and its object are endowed with a spiritual life both simultaneous and coterminous with their natural properties. (Garuba 2003, p. 267)

Disruption of harmonious relationship between man and nature is the highlight of colonialism and Christianity. Many postcolonial critics have argued that this rupture between the man and the nature occurred only because of the book of Genesis which gave humans "domination over the land, seas and animals of the universe. God did not dwell in nature, but ruled over it and he gave to man, his creation the power to do with it whatever man wished" (Cushner 2006, p. 14). This is further testified by the "key theorists of national liberation- including Cesaire, Fanon and Cabral" who "understood colonialism as, among other things, the theft of nature and the ruination of life worlds" (Cited in Potter 2017, p. 381).

The problems of pollution, global warming etc. have proved that the wisdom of Africans who considered Omi-Ala as God was sound when compared to the religion of their 'mutated' progeny. 


\section{Community Efforts to God's Intervention}

Obioma in the novel shows how Christianity dominates the lives of the people. On a closer reading, the readers realise that the people live their lives like automatons who can do nothing except praying to God. It seems that these people have lost control over their lives and their belief that they can change their destinies by working hard. While playing football God is needed for keeping the ball intact, for this Kayode, son of a priest prays for the ball:

Because he couldn't contribute, he prayed for each ball asking God to help us keep this one for much longer by preventing it from crossing the clearing. (p.19)

When the ball crossed the clearing and smashed the windows of the lush house "Kayode knelt and prayed for God's intervention" (p. 20). Jesus's intervention is needed even to save the boys from the beatings of their father. All the boys pray: "Don't allow father to visit again. Let him stay in Yola, please Jesus. Please listen to me: You know how hard he would whip us?” (p. 39).

Obioma shows that conversion to Christianity has made the society static where everything depends on the will of God (p. 161) who controls all the aspects of the life. Obioma criticises deculturing of his people. This is the worst possible condition for the people because they have lost the belief that they can change their destiny by hard work and strong will. In Achebe's Nigeria things were different. Okonkwo becomes rich by his hard work, not by praying to God (201, p.13). Obioma understands that Africa has been "slowly emptied of its essence" by colonial institutions:

Colonialism across most of Africa was so thorough- especially among the former British protectorates- that in its aftermath Africa was essentially hollowed out. The civilizations of the peoples, their various cultures and traditions, their religious, political philosophies and institutions were eroded or even destroyed. (Obioma 2017)

The tragedy of Agwu brothers is that of faith as even to stop the children from wetting the bed, their mother depends on God:

Mother became worried he was under a bed wetting spell. After taking him for sessions of prayers, she began marking the edges of his bed with anointed oil- small bottled olive oil on which prayers had been made- every night before he slept. (186)

The faith of Agwu family leads to tragedy. The novelist assures the readers throughout the novel that a very strong bond of love exists between the brothers (p. 34, 83, 94, 154). Ikenna the eldest of the brothers, loves his younger brothers dearly; but their relationship starts disintegrating after Abulu's prophecy. Abulu prophesises that Ikenna will be murdered by a fisherman.

Ikenna starts thinking that fishermen mean one of his brothers will kill him. Things still remain in control, but Ikenna grows suspicious when Boja, his younger brother, fails to defend him in a fight. He complains: "You didn't fight for me. No! you stood by and watched. Don't even try to deny it” (p. 64). This is the point when Ikenna's psyche starts disintegrating.

\section{Psychic Disintegration}

The hero who saved his brother in a riot (147) becomes suspicious of them and starts destroying everything that showed his love for his brothers and suspicion "robs him of many things- his peace, his well-being, his relationships, his health and even his faith" (p. 128). His suspicion grows to an extent that he stops eating the meals "that were eaten together from the same bowl as his brothers" (p. 128). 
Ikenna's reaction clearly shows that he has acquired a phobia that he will be killed by one of his brothers. Some coincidences accentuate his phobia. His situation matches that is described by Carducci:

A phobia is an intense fear of an object (e.g., a dog) or situation (e.g., enclosed spaces) that is out of proportion to the actual level of danger it presents.... This basic process involves some object or situation that was probably neutral to begin with, but was somehow associated with an extremely high emotional reaction by an individual. (281)

Ikenna fits in the description of Carducci. His brothers in the beginning are "neutral" even affectionate, but after the prophecy of Abulu he becomes suspicious of his own brothers. He becomes a boy with "paranoid personality." Davison and Neale (2001) write:

The individual with paranoid personality disorder is suspicious of others. People with this diagnosis expect to be mistreated or exploited by others and thus are secretive and continually on the lookout for possible signs of trickery and abuse. They are often hostile and react angrily to perceived insults. (p. 360)

Ikenna shows all these traits and after his eccentric behaviour he should have been taken to a doctor. Generally, people rely on God only after exhausting all other options, but for Ikenna's mother the role of doctor has also to be performed by the God. These Nigerians in twentieth century behave like middle age Europeans who used to rely on church for everything and used to brand women as witches, here Abulu is branded as a devil.

In the Middle Ages the church used to burn women as witches to save the society from their bad effect, in twentieth century Nigeria Paulina, Ikenna's mother, tries to find an antidote to Abulu in the Church and Pastor Collins also does not disappoint her. The Pastor declares that Abulu is a "devil" (126) and asks his congregation: "Brethren, you all know that is prophecy is not from God, it is of-" (p. 127) and the congregation replies in unison "the Devil" (p. 127).The Pastor then urges the congregation to "stand and refute that prophecy in the name of Lord Jesus Christ" (127).

The congregation stands up and refutes the prophecy of Abulu in the name of Christ, but the prophecy of Abulu still gets fulfilled and Ikenna gets murdered by Boja in exact fashion as prophesised by Abulu (p. 173). Obioma is clearly critical of over reliance of people on the "totalitarian" religion because in the novel readers see that not even one of the prayers is answered by the Christian God. When Kayode prayed for the ball, the ball gets lost (19), when they pray to Jesus to save them from beatings of their father (p. 39), they are beaten mercilessly (p. 46), prayers certainly do not stop Boja from wetting the bed and despite all the fervour shown by the Pastor and the congregation prayers does not nullify the prophecy of Abulu. But if Ikenna would have been taken to a psychiatrist instead of praying to the God tragedy could have been averted.

Abulu is portrayed as an "evil" (p. 101), a binary opposition to the church and Christianity. He is a man who is not fit to remain in society. He is a mad man who rapes his own mother (p. 112). He commits some more crimes which are unacceptable in the society. He commits necrophilia (p. 251) and desecrates the statue of Madonna:

Solomon then went on to tell us how, in 1993, Abulu was caught clinging to the colourful statue of Madonna in front of the big St. Andrew's Cathedral. Perhaps thinking it was a beautiful woman, who, unlike the other woman he leered at, did not make any move to resist him, he held the statue and began humping against it, moaning, while people gathered, laughing at him until some devotees wrested him off it. (p. 115) 
From the description of Abulu it is clear that Obioma does not approve of Abulu's conduct or his prophecies, but he is critical of over-indulgence in Christianity and over-reliance on God. The novel shows that Nigeria has become like dark ages Europe before the advent of renaissance. In the Middle Ages Europeans did not believe in science and secular sciences, they only had church as an antidote to social, medical, economic and psychological problems. The tragedy of Ikenna and Boja could have been averted by the intervention of a psychologist, but Ikenna's mother is blinded by the colonial faith and could not look beyond it. Obioma drops subtle but powerful hints throughout the novel about how the tragedy occurred because Paulina, Ikenna's mother, went to church instead of a hospital.

Later in the novel she herself develops "a destructive nyctophobia" (p. 218) after the death of her sons; she is taken to a "psychiatric hospital" (p. 217) and she recovers. Ikenna gets killed not because of the prophecy of Abulu or because Abulu's words were the truth; he gets killed because Abulu was considered a 'devil' and only antidote against the devil was with the church. It is because Paulina's thought process was restricted to Christian terminology. Okonkwo's generation of Igbos "saw the Europeans as madmen of strange appearance and ill-formed ideologies" (Obioma 2017) and did not lose their rationality; but Paulina's generation has been blinded by the imported religion.

Obioma following the footsteps of his illustrious predecessor, Chinua Achebe, seems to prefer Igbo worldview of life. This is confirmed by his second novel An Orchestra of Minorities (2019) where Chi is the narrator. In The Fishermen too, he seems to suggest that Igbo religion and world view is part and parcel of their beings, but it is suppressed by their Christian upbringing. Ikenna's father seems to represent "Africa's elites" (Obioma 2017) who thinks that the best way to become modern is to follow institutions of the whites including western education and Christianity.

He ensured that his sons will get educated in western education; but once he gets transferred to Yola his grip eases over the boys and they start drifting towards Igbo life style. Fishing probably is symbolic of the life style followed by their ancestors; the idea is reinforced by the fact that Omi-Ala was considered as a god in pre-colonial times. Of course, the river in pre-colonial times was teeming with fish and clean drinking water; in post-colonial times it has become a drain of bracken water. Towards the end of the novel Ikenna's father also seems to have attained his Igbo attributes. He appreciates Benjamin for killing of Abulu: "what you have done is great. Genti, eh. Do not regret it" (p. 329). Killing of Abulu represents Igbo concept of justice where a person who has done wrong to the society may be killed.

By acknowledging the murder of Abulu as 'great' Ikenna's father James acknowledges the "violence within" Igbo culture where "offenders" (Hoegberg 1999, p. 70) were punished. Thus, James also realises that killing of Abulu comes under the scope of "culturally sanctioned violence" (Hoegberg 1999, p. 71) because Abulu posed a threat to the whole society.

\section{Setting the History Right?}

The novel is "an exercise in historical recuperation" (Begam 1997, p. 397) because it foregrounds the historical mistakes that have been committed by Africans in general and Nigerians in particular. The novel seems to suggest that the bag and baggage of colonial institutions should have been dropped after achieving impendence from the colonial rule. The historical mistake of retaining the colonial institutions was made by the Africans because of the cultural amnesia induced by the policies of the whites. 
These institutions thrust an inferiority complex on the people and convinced them that they were barbarians before the arrival of the colonisers. The African writers have been trying to resurrect the image of Africa and this is done by comparing Africa with the Europe. According to Wallerstein (1961), the Europeans:

Developed patriarchal systems characterized by suppression of woman and a propensity for war. Also associated with such societies are materialist religion, sin and guilt, xenophobia, the tragic drama, the city state, individualism and pessimism. Southerners on the other hand, are matriarchal. The women are free and the people peaceful; there is a Dionysian approach to life, religious idealism, and no concept of sin, with a matriarchal society came xenophilia, the tale as a literary form, the territorial state, social collectivism and optimism. (p. 129-30)

Obioma also seems to be a supporter of the above statement that western religion induces the feelings of sin and guilt among its adherents. In his short story "The Great Convert" (2014) he seems to elaborate how these feelings of sin and guilt can play havoc with a person. In the story Father Paul, tells his new convert Nathan:

Hence the teaching that if you just can't stay without stealing, then cut your arm rather than have your whole body thrown into hell. If your eyes move you to lust, better to pluck them out than have your whole body thrown into hell. (p. 151)

This teaching upsets Nathan as he is "used to lusting after things -money, women and all" (p. 151). To save himself from hell he dies while "trying to pluck his eyes" (p. 152). This concept of guilt and sin is alien to the Igbos who believe in the existence of other world where the ancestors live after death.

\section{Distanced through Language}

Though the issues regarding Christianity dominate the novel, Obioma is also critical of other colonial institutions. One of the important things he mentions is the adaptation of English as the national language of Nigeria. Cheikh Anta Diop commented in an interview with Carlos Moore that "flight from one's own language is the quickest short cut to cultural alienation" (Moore 1989, p. 407). This happens in the novel also, where the children fail to understand their own Igbo language:

Our parents often found the need to explain such expressions containing concealed meanings because we sometimes took them literally, but it was the way they learned to speak; the way our language -Igbo- was structured. (p. 54)

The above passage shows cultural alienation of the children where they are not able to understand their own language. This means that the cultural codes embedded in their language will remain alien to them. English as a language did not perform the function it was supposed to do:

English, although official language of Nigeria, was a formal language with which strangers and non-relatives addressed you. It had the potency of digging craters between you and your friends or relatives if one of you switched to using it. (p. 35-36)

English language is a vestige of colonial era that has to be done away with. English is important so it may be given a status of the connecting language, but it should not be given more importance than the indigenous language. This is what Ngugi wa Thiong'o calls the "conscious elevation of the language of colonisers" (2007, p. 17). Language according to Thiong'o is "a carrier 
of culture" (2007, p. 13). Once the language vanishes the culture will also vanish. In the novel, readers realize that the process of forgetting one's language has already begun in Nigeria. Mr. James Agwu times and again emphasises the importance of learning English to his children.

Moreover, when the government has indirectly declared that Nigerian languages are inferior to English, their future is certainly doomed. Ngugi wa Thiong'o observes: "Culture develops within the process of a people wrestling with their natural and social environment" (1993, p. 45). This means the language that developed alongside culture is a repository of the wisdom acquired over the centuries. Once the language vanishes, the wisdom also vanishes. Obioma tells again and again that the children of Agwu household are more proficient in English when compared to Igbo or Yoruba: "our parents most often reverted to English when angry because being angry they didn't want to explain whatever they said" (p. 54).

\section{Enter: The African Novelist}

This is clear that Obioma takes up things from where Achebe left. Achebe remarked that business of "a novelist was to teach, to re-educate his society out of their acceptance of social inferiority" (Thiong'o 1972, p. 51). Achebe further said:

Here then is an adequate revolution for me to espouse- to help my society regain its belief in itself and put away the complexes of the years of denigration and self- denigration. (Cited in Thiong'o 1972, p.51)

Chinua Achebe tried to accomplish the job by piercing the veil of colonialism and trying to present the true image about his society and culture. Obioma tries to accomplish the same thing by exposing what colonial institutions have done to Nigeria.

He seems to suggest that Nigerians committed a mistake by adopting colonial institutions instead of developing their own national culture. Obioma vindicates the ideas of Frantz Fanon who made a desperate call to all the colonised countries to develop a national culture:

The claim to a national culture in the past does not only rehabilitate that nation and Serve as a justification for the hope of a future national culture. In the sphere of psycho-affective equilibrium for an important change in Native. (p. 209)

Instead of developing a national culture, Nigeria relied on western institutions to get a tag of modernity. It is clear that post- independence Nigeria acted to become 'modern' in the eyes of Europe instead of acting in self-interest. They achieved physical independence in favour of mental slavery. Sagging under the weight of inferiority complex Nigeria did not try to preserve and develop her own culture, rather thrust an alien culture on the people in hope of becoming modern in the eyes of Europe. Obioma writes about this dichotomy of the African nations:

Today most of the nations in Africa should not even be called African nations, but western African nations. The language, political ideology, socio-economic structures, education, and everything that makes us up a nation, even down to popular culture, do not originate from within these countries. African nations have a total dependency on foreign political philosophies and institutions, and their shifts and movements. (Obioma 2017)

In The Fishermen Obioma seems to be very critical of western education. In the novel James Agwu seems to approve only one kind of education: western education. He tells the children: "I sweat and suffer to send you to school receive a western education as civilized men, but you chose instead to be fishermen. Fish-a-men!" (p.46). When one analyses the statement of James Agwu one 
realises that in his point of view western education is the only education that is capable of civilizing human beings. He comes across as an artefact of colonialism, a perfectly chiselled object of white institutions who has been shorn off his culture and pride by colonial institutions.

Here he vindicates the ideology of the colonisers who claimed that Africa was a barbaric land before the arrival of the whites. By inadvertently agreeing to this colonial propaganda, he confesses that Africans were uncivilized before the arrival of the whites. This kind of a person is a nightmare for African intellectuals like Frantz Fanon, Ngugi wa Thiong'o and most importantly Chinua Achebe who throughout his life tried to convince the world that Africa was not savage before arrival of the whites.

In the novel, western education seems to be a binary opposition to the African life style. James Agwu tells his children: "Listen what you did was truly bad. Bad. Just how could kids receiving western education engage in such a barbaric endeavour?" (p.48). Here western education is supposed to make them forget "barbaric endeavour" of fishing, it seems Mr. Agwu did not have any chance of reading Ernest Hemingway's fiction who glorified fishing in his novels, but it becomes clear that Western education is supposed to erase the barbaric behaviour. He fails to realise that these institutions were made to de-racinate or de-culture them. James Agwu's thinking process shows that these institutions were successful in accomplishing what they were meant to do. Cheikh Hamidou Kane wrote about efficiency of Western education:

On the Black continent, one began to understand that their real power resided not at all in the cannons of the first morning but in what followed the cannons. Therefore, behind the cannons was the new school. The new school had the nature of both the cannon and the magnet. From the cannon it took the efficiency of a fighting weapon. But better than the cannon it made the conquest permanent. The cannon forces the body and the school fascinates the soul. (Cited in Thiong'o 2007, p. 9)

Obioma testifies that the soul of the Nigerians has been held prisoner by the white institutions. The empire has ended, but it still exercises control over the souls of Nigerians by these institutions. "The physical subjugation" has ended but "spiritual subjugation" (Thiong'o 2007, p.9) continues through western education.

\section{Efficacy of Democracy?}

Obioma criticises not only Christianity and western education; but also, democracy which is sacrosanct in the contemporary world. In the postcolonial world democracy is considered the best gift that has been offered by the west. It has been visualised as an ideal system of government where everybody has a say in the formation of a government. Obioma puts question mark on democracy in an interview with Shreya Mallika Datta. He asks: "Is democracy as everyone argues is best-really best for us? Should we be swearing our politicians into office with the Bible or at shrines?" (2020, p. 58).

In The Fishermen, he shows that democracy is just another colonial institution that has become a breeding ground for corruption and violence. This system of governance has proved useless for Nigeria. Nigeria has become a volatile country due to democracy where violence and riots occur on regular basis and this violence is generally targeted against a particular ethnic group (p. 15, 147). Obioma makes it clear that most of violence is political in nature where one ethnic group wants to subdue another. In the beginning of the novel, Obioma tells the readers: "Yola.... Was a volatile city with a history of frequent large-scale violence against people of our tribe - the 
Igbo. We continued to push him until the bloody sectarian riots of March 1996 erupted" (p. 15). While describing another riot he writes:

We could tell from the man's attire- a long, flowing Senegalese robe- that he was a northerner: the main targets of the onslaught by M.K.O. Abiola supporter, who'd hijacked the riot as a struggle between his west, and the north, where the, military president, General Babangida belonged. (p. 147)

Obioma shows that these "internecine political riots" (p. 142, 148) were the result of continuing power struggle between the different ethnic groups of the country.

Due the rivalry between different sections of the society, assassinations are also common in the country:

A year after I got into prison, in 1998, Evangelist Ajayi brought news that General Abacha, the dictator, died frothing at the mouth, and news floated that a poisoned apple had killed him. Then exactly one month later, as he was about to be released, Abacha's prime prisoner and arch enemy, M.K.O. died much the same way- after drinking a cup of tea. (p. 337)

Violence is not the only aspect of Nigeria's democracy which has been punctuated at regular intervals by military dictatorships. The graver concern is that democracy has failed to solve the problems of Nigeria. Nigeria suffers from poverty (p. 137) despite being oil rich, poor health facilities (p. 41) and corruption (p. 235).

Chinua Achebe warned about corruption that will emanate from colonial institutions in his novel No Longer at Ease (2010, p. 3, 15, 16, 25, 31). The problem has only exacerbated with the passage of time. Obioma writes in an article:

It was the rich soil from which the dark flowers of bribery, favouritism, opportunism and all forms of corruption sprouted, stretching their protean tendrils into every sector of society. When a Nigerian sees an advertisement for a job opening, she or he simply goes to find someone who might be connected to someone at the top of the firm. To the typical Nigerian, the ad is purely informational, a notification that there is an opening; it is not an invitation to apply. (Obioma 2016)

This corruption also seems to be a direct outcome of democracy because powerful people want to create permanent power structures so they want their own people to occupy key positions. This corruption from the top positions permeates to all lower departments like that of police (p. 190). Obioma wants Nigerians to reject democracy in favour of indigenous government systems:

The most viable pathway would be for Africa's elite to look within the vast political and ideological resources on which successful civilizations (The Zulu, The Igbo, The Malian dynasties of Timbuktu, the Oyo empire, etc.) were built. In most Igbo states, for instance, there was an egalitarian system where an older member of a clan represented his people in the elder's council. There were no kings or presidents. Perhaps there could be a way to adopt this unique political structure to replace the western one has so far failed. (Obioma 2017)

The glimpses of this system (Igbo) were given by Chinua Achebe in the novel Things Fall Apart. The Igbos were ruled by a kind of "gerontocracy" (Briscoe 1993, p. 151). In this system all the villages of clan were represented by the old and respectable people of the clan. The faces of governing council members of egwugwu (Achebe 2001, p. 65) were covered with masks so that nobody could recognise them and approach them. Corruption in the system was ruled out and justice was available to everybody without spending even a single penny. Justice was delivered swiftly. In Things Fall Apart, 
Achebe shows the case of Mgbafo being presented before the egwugwu (p. 66). Achebe also tells us that Okonkwo is also a member of egwugwu (p. 66). Okonkwo's treatment of his wives is marked by "his personal rashness and high-handedness" (Ojaide 1977 p.172), but Okonkwo as one of the egwugwu chastises and fines the abusive husband" (Ojaide 1997, p. 172). This shows objectivity of Okonkwo as a judge. Moreover, there are many judges in this traditional court which means that the judicial system cannot be manipulated.

Thus, the novel The Fishermen presents a critique of the problems that are faced by Nigeria. Obioma thinks that Nigeria needs "an overhauling for rehabilitation" (Datta, p. 58). In the novel, he shows how colonial institutions are playing havoc with Nigeria. If Nigeria has to redeem itself then it has to visit its history and resuscitate the institutions which were devised by people according to the needs. The redemption of Nigeria lies in developing and nurturing a national culture rather than becoming a "western African state."

\section{Conclusion: Canon, anti-canon, new Canon?}

As successive authors add to discourse that challenges the received or established Western notions, a new body of writing emerges that is characterized by an alternative point of view salvaging a past and giving glimpses of a history almost obliterated by hegemonic operations of the erstwhile colonial powers. The imaginative appeal, the fictional quotient and the intellectual earnestness with which these texts approach culture, history and people have made these works or body of this writing create a niche space for themselves- a contemporary 'canon', an anti-canon or the new canon. This novel canon is an academic paradox.

\section{References}

Achebe, Chinua. (1973). The Role of the Writer in a New Nation. In G.D. Killan (Ed.)

African Writers on African Writing. Evanston: North Western University Press. Pp. 7-13.

Achebe, Chinua. (2001). Things Fall Apart. London: Penguin.

Achebe, Chinua. (2010). No Longer at Ease. London: Penguin.

Begam, Richard. (1997). Achebe's Sense of an Ending: History and Tragedy in “Things Fall Apart.” Studies in the Novel 29.3 (Fall), 396-441.

Bonetti, Kay. (1989). An Interview with Chinua Achebe. The Missouri Review 12.1, 61-83.

Briscoe, Gordon. Aboriginal Australian Identity. The Historiography of Relations between various Ethnic Groups and Other Australians 1788 to 1988. History Workshop Journal 36 (Autumn), 133-161.

Carducci, Bernardo J. (1998). The Psychology of Personality. Pacific Grove: Brooks/Cole Publishing Company. Courtois, Cedric. (2019). "Revolutionary Politics" and Poetics in the Nigerian

Bildungsroman: The Coming-of-Age of the Individual and Nation in Chigozie Obioma's The Fishermen. Commonwealth Essays and Studies 42.1, 1-14.

Cushner, Nicholas P. (2008). Why Have You Come Here? The Jesuits and The First Evangelization of Native America. New York: Oxford University Press.

Datta, Shreya Mallika. (2020). Silence is the Tool of Unconcerned: An Interview with Chigozie Obioma. Wasafiri 35.1, 57-62.

Davison, Gerald C. and John M. Neale. (2001). Abnormal Psychology. New York: John Wiley \& Sons. 
Diop, Cheikh Anta. (1991). Civilization or Barbarism. Trans. Yaa-Lengi Meema Ngemi. New York: Lawrence Hill Books.

Fanon, Frantz. (1963). The Wretched of the Earth. Trans. Contance Farrington. New York: Grove Press.

Garuba Harry. (2003). Explorations in Animist Materialism: Notes on Reading/Writing African Literature, Culture and Society. Public Culture 15.2, 261-286.

Gikandi, Simon. (2001). Chinua Achebe and Invention of the African Culture. Research in African Literatures. 32.3, 3-8.

Hoegberg, David. (1999). Principle and Practice: The Logic of Cultural Violence in Achebe's Things Fall Apart. College Literature 26.1 (Winter), 67-79.

Irele, F. Abiola. (2009). Introduction. In F. Abiola Irele (Ed.) The Cambridge Companion to the African Novel. Cambridge: Cambridge University Press. Pp. 31-50.

Izevbaye, Dan. (2009). Chinua Achebe and the African Novel. In F. Abiola Irele (Ed.) The Cambridge Companion to the African Novel. Cambridge: Cambridge University Press. Pp. 31-50.

Kadiatu, Kanneh. (1998). African Identities. London: Routledge.

Kortenaar, Neil Ten. (1995). How the Centre is Made to Hold in Things Fall Apart. In Michael Parker and Roger Starkey (Ed.) Postcolonial Literatures: Achebe, Ngugi, Desai, Walcott. London: Macmillan Press Ltd. Pp. 31-52.

Moore, Carlos. (1989). Conversations with Cheikh Anta Diop. Presence Africaine 149-150.

Obioma, Chigozie. (2014). The Great Convert. Transition 114, 146-162. Retrieved on Jan. 2010 from JSTOR.

Obioma, Chigozie. (2015). The Fishermen. London: One.

Obioma, Chigozie. (2017). Africa has been Failed by Westernization. It must Cast off its Subservience. Retrieved from<www.theguardian.com/commentsfree/2017/nov/12/africa-failed-by-westernizationmust-cast-off-its-subservience?cmp=share.html.>

Obioma, Chigozie. (2019). An Orchestra of Minorities. London: Abacus.

Ojaide, tenure. (1997).African Literature and Its Context: Teaching Teachers of Chinua Achebe's "Things Fall Apart." Women's Studies Quarterly 25.3/4 (Fall-Winter), 169-177.

Osei-Nyame, Kwado.(2010). Chinua Achebe Writing Culture: Representative of Gender and Tradition in Things Fall Apart. In Harold Bloom (Ed.) Chinua Achebe's Things Fall Apart. New York: Infobase Publishing. Pp. 5-22.

Potter, Lucy. (2017). Postcolonial Resources, Pedagogical Resistance: An Energy Driven Interview with Professor Jennifer Wenzel. Journal of Postcolonial Writing 53.3, 265-276.

Rocco, Fiammetta. (2015). 'The Fishermen' by Chigozie Obioma. Retrieved from www.nytimes.com/2015/books/review/the-fishermen-by-chigozie-obioma-html.

Rhoads, Diana Akers. (1993). Culture in Chinua Achebe’s Things Fall Apart. African Studies Review 36.2 (Sept.), 61-72.

Thiong'o, Ngugi wa. (1972). Chinua Achebe: A Man of the People. In Homecoming. London: Heinemann, 5154 .

Thiong'o, Ngugi wa. (1987). Decolonizing the Mind. Harare: Heinemann Educational.

Thiong'o, Ngugi wa. (1993). Moving the Centre: The Struggle for Cultural Freedoms. London: James Curry. Wallerstein, Immanuel. (1961). Africa: The Politics of Independence. New York: Vintage Books. 